\title{
Environmentálně rizikové chemické prvky na odkališti Brno-Hády
}

\author{
Environmentally hazardous chemical elements at the Brno-Hády landfill
}

\author{
Václav Hladík ${ }^{\square}$, Jindřich Štelcl ${ }^{1,2}$ \\ ' Ústav geologických věd PřF MU, Kotlářská 2, 61137 Brno, ČR \\ ${ }^{2}$ Katedra biologie, Pedagogická fakulta, Masarykova univerzita, Poříči 7, 60300 Brno, ČR
}

\section{Key words:}

Waste dump Brno-Hády, fly ash, heavy metals, radioactive elements, microsphere, arsenic

\section{$\square$ hlad.v@mail.muni.cz}

Editor:

Jiří Faimon
Doporučená citace článku: Hladík, V., Štelcl, J. (2021). Environmentálně rizikové chemické prvky na odkališti Brno-Hády. Geologické výzkumy na Moravě a ve Slezsku, 28, 1-2, 7-12.

https://doi.org/10.5817/GVMS202114056

\begin{abstract}
The studied area is located in Brno-Vinohrady. This location was used for fly ash dumping. Fly ash as a product of coal combustion was deposited there in period from 1967 to 1997 from the in the Červený mlýn and Špitálka heating plants. This material has the ability to absorb pollutants, especially heavy metals in its structure. Elevated concentrations of these elements thus represent a potential environmental risk. The main impulse to have a closer look at this waste dump and the fly ash composition is the planned building of a leisure complex in this area in the near future.

The fly ash morphology was investigated by a scanning electron microscope (SEM). The results proved the presence of microspheres. On their surface, heavy metals and other contaminants can be accumulated. The contents of heavy metals were determined in the studied material by atomic absorption spectroscopy (AAS) and X-ray fluorescence (XRF) analysis. Measured values were compared with the limit values of environmental pollution published by the Ministry of the Environment of the Czech Republic and with the results of previous studies from the same place. The limits were exceeded slightly by cobalt (Me $=41.62$ ppm; Max = 58.30), and a lot of arsenic $(M e=380.62 ;$ Max =593.35). Amount of arsenic was thus compared with the exposure models, which were created for this location earlier. Its concentration transgressed the line of potential risk for a human organism. The number of radionuclides in the analyzed material by laboratory gamma-ray spectrometry (Me: $K=1.75 \%, e U=6.50 \mathrm{ppm}, e \mathrm{Th}=16.75 \mathrm{ppm}$ ) was converted to the specific activity of ${ }^{226} \mathrm{Ra}\left(a_{\mathrm{m}} ; \mathrm{Me}=212.40 \mathrm{~Bq} \mathrm{\textrm {kg } ^ { - 1 }}\right)$ and compared with the limit which is $370 \mathrm{~Bq} \mathrm{~kg}$. This method proved that the deposited material does not contain potentially dangerous amounts of natural radionuclides.

Based on the results of this study, especially on the amount of arsenic, the waste dump BrnoHády represents a potentially dangerous location for the human organism and requires adjustments for possible future utilization as a leisure complex.
\end{abstract}

\section{Úvod}

Na ploše bývalého odkaliště popílků Brno-Hády (obr. 1) je již dlouhodobě plánováno vybudování volnočasového areálu pro přilehlé městské části Vinohrady a Líšeň. Materiál, který zde byl deponován v období let 1967-1997 (Ondráček 2009), obsahuje polutanty a přirozené radioaktivní prvky (Fečko et al. 2003). Z tohoto důvodu může jeho prrítomnost na lokalitě představovat potenciální nebezpečí pro přilehlý ekosystém včetně lidského organismu. Toto riziko je v poslední době vlivem stoupajícího rekreačního využití stále aktuálnější. Lze předpokládat, že vybudováním parku by došlo ke zvýšení potenciálu ohrožení jeho návštěvníků. Cílem provedeného výzkumu tak bylo posouzení 
environmentálního rizika ve studovaném území a posouzení jeho vhodnosti k případnému rekreačnímu využití. První průzkum sloužící k ověření nezávadnosti lokality byl proveden již v průběhu roku 1997. Potenciální riziko představovala podle jeho výsledků pouze vyšší koncentrace arsenu, ale to až v hloubce okolo sedmi metrů pod povrchem (Moric 1997). Významným příspěvkem k problematice bývalého odkaliště byla práce Ondráčka (2009), který rovněž vytvořil expoziční modely pro případ rekreačního využití dané lokality. Tyto modely pracují s několika faktory, mezi než patří například koncentrace chemické látky, doba trvání expozice a její frekvence, objem inhalovaného vzduchu nebo průměrná hmotnost dospělého člověka. Autor v uvedené studii rovněž upozorňuje na lokálně zvýšené koncentrace As s jeho negativním účinkem na lidský organismus. Další výzkumy uskutečněné na odkališti v uplynulých letech (Doleželová 2013; Př́ikazská 2017) vyšší koncentrace As potvrdily, a to již ve svrchní části horizontu.

\section{Geologické poměry}

Podloží odkaliště tvoří biotitické granodiority brněnského batolitu, které Štelcl a Weiss eds (1986) označují jako typ Královo Pole. V prostoru zájmového území přecházejí krystalinické horniny ve své svrchní části do eluvia majícího charakter písků až štěrků s úlomky nezvětralé horniny, a to především ve východní části odkaliště, kde dosahují mocnosti až $10 \mathrm{~m}$. Jeho západní plochu budují nad granitoidním podložím zejména kvartérní spraše a hrubozrnné štěrky vyšší terasy Svitavy (obr. 1). Nejsvrchnější vrstvu reprezentují produkty spalování uhlí - popílky, dovážené a sypáním uložené z teplárny

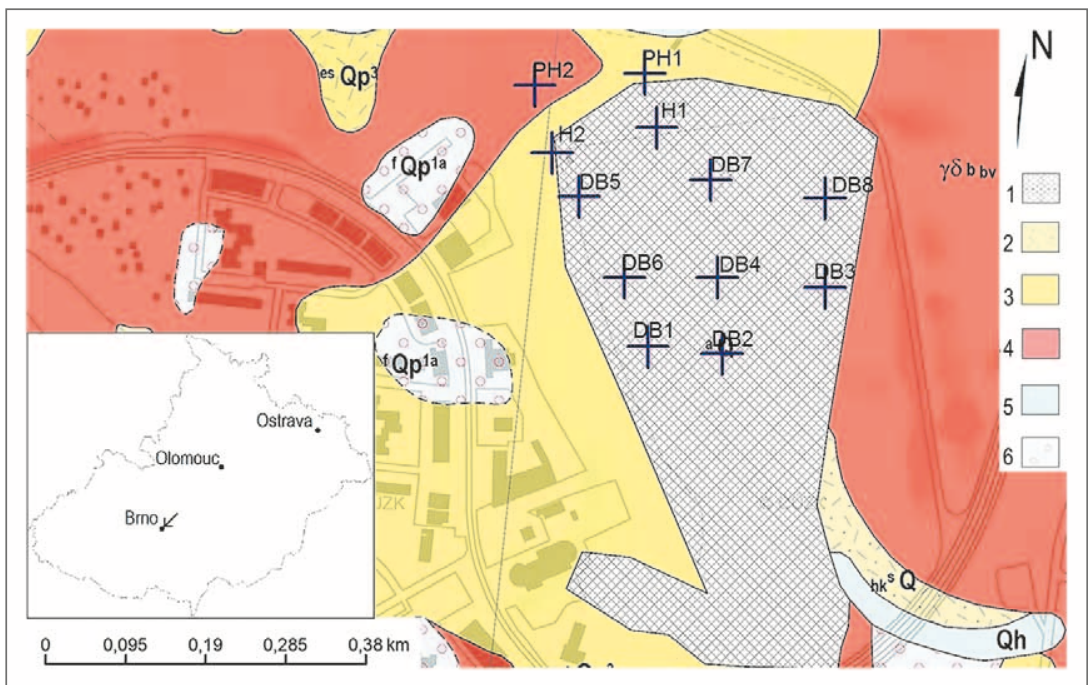

Obr. 1: Mapa zájmové lokality (podle Hanžl ed. 2020; Gilíková a Hladil eds. 2010, upraveno); 1 - antropogenní uloženiny nerozlišené (současná plocha odkaliště); 2 - svahové hlinitokamenité až kamenitohlinité sedimenty; 3 - spraše a sprašové hlíny; 4 - stř̌edně až hrubě zrnitý biotitický granodiorit; 5 - splachové písčitohlinité sedimenty; 6 - fluviální písčité štěrky (vyšší úroveň). Odběrové body jsou označeny křížkem.

Fig. 1: The map of the locality (according to Hanžl ed. 2020, Gilíková a Hladil eds. 2010, modified); 1 - anthropogenic deposits undifferentiated (the current area of the waste dump); 2 - colluvial aluminous to stony clay deposits; 3 - loess and loess clay; 4 - medium to coarse-grained biotite granodiorite; 5 - wash sandy loam sediments; 6 - fluvial sandy gravel (a higher level). Sampling points are marked with a cross.
Červený mlýn a naplavované ve vodní suspenzi potrubím z teplárny Špitálka v areálu odkaliště v období let -1997. Jižní polovina bývalého odkaliště je díky reprovést odběry vzorků. Průměrná mocnost popílků činí na lokalitě $11 \mathrm{~m}$, přičemž jejich celkové množství dosahuje $1540000 \mathrm{~m}^{3}$. Mimo popílků zde byly v minulosti uloženy rovněž vápenné a vápenoželezité kaly o objemu $136800 \mathrm{~m}^{3}$ (Ondráček 2009).

\section{Metodika}

$\mathrm{V}$ rámci studia bylo na ploše odkaliště pomocí narážecí sondy odebráno osm vzorků (DB1-DB8) z hloubky 1-2 m pod povrchem (obr. 1). Tyto vzorky byly analyzovány na stanovení obsahu vybraných prvků prostřednictvím atomové absorpční spektrometrie (AAS) a rentgenové fluorescenční analýzy (XRF). Z dokumentačních bodů rovněž odebrány povrchové vzorky popílků $\mathrm{k}$ pojejch struktury pomocí elektronového mikroskopu posouzení obsahu prirozených radioaktivních prvkủ. ohrožení okolního ekosystému odebrány další čtyři zorky, a to dva z prostoru s. hráze $(\mathrm{H} 1, \mathrm{H} 2)$ a z prostoru touto hrází (PH1, PH2) - viz obrázek 1. Tyto vzorky byly odebrány kopanou sondou z hloubky cca $25 \mathrm{~cm}$ a byly

Ke studiu morfologie částic popílků byl použit elektronový skenovací mikroskop JEOL JSM 6490LV (operátor Stelcl). Vysušení vzorků proběhlo při teplotě $40{ }^{\circ} \mathrm{C}$ do konstantní hmotnosti. Vysušené vzorky byly nalepeny na uhlíkovou pásku a následně vakuově pokoveny zlatem. Snímkování proběhlo v režimu zpětně odražených elektronů při urychlovacím napětí $15 \mathrm{kV}$.

Stanovení koncentrací $\mathrm{K}, \mathrm{U}$ a Th bylo provedeno laboratorním gamaspektrometrem SG-1000LAB vybaveným scintilačním NaI:Tl detektorem o objemu $0,35 \mathrm{dm}^{3}$. Koncentrace draslíku byly zjištovány na základě aktivity ${ }^{40} \mathrm{~K}$, koncentrace $\mathrm{U}$ a Th neprímo na základě aktivity jejich dceřiných produktů (tyto koncentrace jsou tak v dalším textu označovány jako eU a eTh). Před vlastním měřením byly vzorky vysušeny a uzavřeny do plastových pouzder, v nichž byly uskladněny po dobu 25 dní za účelem ustálení radioaktivní rovnováhy. Naměřené hodnoty byly převedeny na hmotnostní aktivitu ekvivalentu ${ }^{226} \mathrm{Ra}\left(\mathrm{a}_{\mathrm{m}}\right)$. K vlastnímu výpočtu byly použity následující přepočtové koeficienty (Beretka, Matthew 1985): $1 \% \mathrm{~K}$ v hornině = $313,00 \mathrm{~Bq} \mathrm{~kg}^{-1}{ }^{40} \mathrm{~K}, 1$ ppm U v hornině $=12,35 \mathrm{~Bq} \mathrm{~kg}^{-1}{ }^{226} \mathrm{Ra}, 1 \mathrm{ppm}$ 
Th v hornině $=4,06 \mathrm{~Bq} \mathrm{~kg}^{-1}{ }^{232} \mathrm{Th}$. Hmotnostní aktivita pak byla vypočtena pomocí vztahu: $\mathrm{a}_{\mathrm{m}}=12,35 \mathrm{U}+(1,43$ $\times 4,06 \mathrm{Th})+(0,077 \times 313 \mathrm{~K})$.

Stanovení vybraných kovů a polokovů probíhalo metodou AAS, kontrolní stanovení pak méně přesnou metodou XRF. Pro potřeby obou uvedených metod byly jednotlivé vzorky předem vysušeny a sítovány na zrnitost $<0,5 \mathrm{~mm}$. V případě AAS byly analyzované vzorky navíc nadrceny $\mathrm{v}$ achátovém drtiči a rozpuštěny roztokem kyseliny chloristé a kyseliny fluorovodíkové. Získané roztoky byly analyzovány spektrometrem SOLAAR M5 TJA (analytik P. Kadlec).

Pro rtg-analýzu byly vysušené práškové vzorky lisovány do tablet. Tablety byly analyzovány na př́tomnost těžkých kovů, primárně však na množství rtuti, kterou nelze zachytit metodou AAS, a to pomocí stolního energiově disperzního rtg-fluorescenčního spektroskopu (ED-XRF) s polarizovaným svazkem Rigaku NexCG (analytik K. Slavíček). Př́ístroj je vybaven Pd anodou o výkonu $50 \mathrm{~W}$ a SSD detektorem s rozlišením 145 eV a využívá nepřímé excitace pomocí sekundárních terčíků $\mathrm{k}$ docílení lepšího poměru signál-šum. Délka měření činila 300 sekund na každý terčík. V̌̌echny analytické práce byly provedeny v laboratořích Ústavu geologických věd PřF MU.
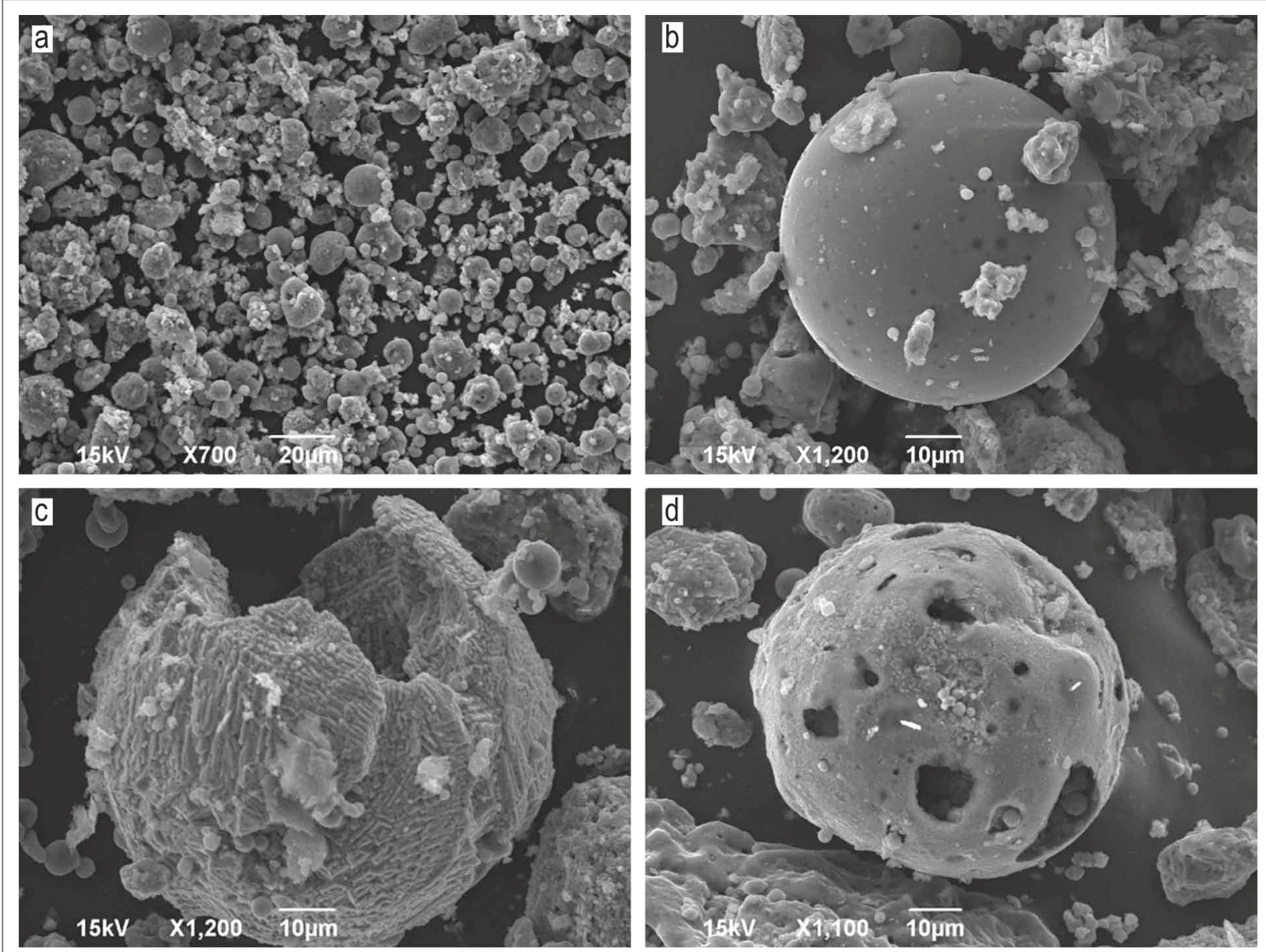

Obr. 2: Mikrofotografie popílku; a - morfologie popílků - mikrosféry a částice nedopalu; b - mikrosféra obklopená částicemi nedopalu; c - perforovaná cenosféra; d - plerosféra vyplněná menšími mikrosférami. BSE snímky.

Fig. 2: Microphotos of the fly ash: a - morphology of fly ash - microspheres and unburned carbon particles; $\mathrm{b}$ - microsphere surrounded by unburned carbon particles; $\mathrm{c}$ - perforated cenosphere; $\mathrm{d}$ - plerosphere filled with smaller microspheres. BSE images.

\section{Výsledky a diskuze}

Popílky pocházející z odkaliště Brno-Hády jsou morfologicky tvořeny převážně dvěma typy částic, a to „spečenými“ nepravidelně omezenými zrny nedopalu a mikrosférami (obr. 2a, 2b). Tyto kulovité částice jsou typickými produkty vysokoteplotního spalování uhlí a lze mezi nimi rozlišit duté cenosféry (obr. 2c) a plerosféry, které jsou místy vyplněny drobnějšími mikrosférami (obr. 2d). Velmi hrubý povrch mikrosfér umožňuje vznik povlaků usnadňujících akumulaci případných polutantů (Fečko et al. 2003). Velikost pozorovaných mikrosfér (2,5-90,0 $\mu \mathrm{m})$ je nižší oproti velikosti udávané v odborné literatuře $(20-200 \mu \mathrm{m})$. Větší měrný povrch může být jednou $\mathrm{z}$ prŕčin vyššího obsahu mikročástic $\mathrm{v}$ povlacích mikrosfér, a tím i větší pravděpodobnosti akumulace potenciálních kontaminantů.

K posouzení potenciálního rizika ohrožení okolního ekosystému byly pomocí AAS porovnány vzorky pocházející z vlastní plochy odkaliště (DB1-DB8) z prostoru hráze (H1 a H2) a severně pod touto hrází (PH1, $\mathrm{PH} 2$ ). Materiál byl analyzován s důrazem na př́tomnost a obsah mědi, zinku, olova, kobaltu, niklu, kadmia a arsenu (tab. 1).

Koncentrace $\mathrm{Cu}$ na ploše vlastního odkaliště se pohybuje v rozmezí od 32,77 (DB3) do 101,35 (DB2) ppm, 
Tab. 1: Koncentrace těžkých kovů [ppm] na ploše odkaliště; $<$ DL - Koncentrace pod detekčním limitem; DL - Průměrná hodnota detekčního limitu.

Tab. 1: Concentrations of heavy metals in the area of the waste dump [ppm]; $<\mathrm{DL}-\mathrm{A}$ concentration below the limit of detection; DL - An average value of the limit of detection.

\begin{tabular}{|l|c|c|c|c|c|c|c|}
\hline & Cu & Zn & Pb & Co & Ni & Cd & As \\
\hline DB1 & 86,86 & 155,16 & 14,06 & 46,70 & 107,45 & $<\mathrm{DL}$ & 383,77 \\
\hline DB2 & 101,35 & 233,07 & 47,75 & 32,66 & 106,45 & $<\mathrm{DL}$ & 377,46 \\
\hline DB3 & 32,77 & 118,94 & 0,00 & 0,00 & 24,48 & $<\mathrm{DL}$ & 80,39 \\
\hline DB4 & 88,70 & 164,74 & 18,75 & 39,38 & 109,89 & $<\mathrm{DL}$ & 438,91 \\
\hline DB5 & 84,78 & 199,62 & 24,48 & 43,86 & 109,92 & $<\mathrm{DL}$ & 324,20 \\
\hline DB6 & 87,58 & 213,81 & 32,59 & 48,64 & 105,85 & $<\mathrm{DL}$ & 593,35 \\
\hline DB7 & 88,16 & 144,18 & 0,00 & 58,30 & 120,20 & $<\mathrm{DL}$ & 224,48 \\
\hline DB8 & 85,41 & 189,81 & 27,00 & 39,34 & 111,12 & $<\mathrm{DL}$ & 390,77 \\
\hline PH1 & 35,20 & 105,50 & 15,80 & 9,00 & 52,10 & $<\mathrm{DL}$ & $<\mathrm{DL}$ \\
\hline PH2 & 6,70 & 68,40 & $<\mathrm{DL}$ & $<\mathrm{DL}$ & 18,10 & $<\mathrm{DL}$ & $<\mathrm{DL}$ \\
\hline H1 & $<\mathrm{DL}$ & 76,40 & $<\mathrm{DL}$ & $<\mathrm{DL}$ & 16,70 & $<\mathrm{DL}$ & $<\mathrm{DL}$ \\
\hline H2 & $<\mathrm{DL}$ & 82,30 & $<\mathrm{DL}$ & $<\mathrm{DL}$ & 15,10 & $<\mathrm{DL}$ & $<\mathrm{DL}$ \\
\hline DL & 10,25 & & 25,00 & 20,25 & & 8,00 & 95,00 \\
\hline
\end{tabular}

zatímco v okolí odkaliště jsou zaznamenané hodnoty Cu nižší s naměřeným maximem 35,20 ppm. Relativní rozdíl obsahů zinku ve vzorcích odebraných na zájmové ploše a za její hranicí je ze všech těžkých kovů nejnižší. Obsahy zjištěné v zájmové oblasti se pohybují od 118,94 (DB3) do 233,07 (DB2) ppm, maximum koncentrací tohoto prvku mimo vlastní plochu odkaliště dosahuje hodnoty 105,50 ppm, a je tedy nižší než minimum zjištěné v zájmové ploše (odběrového bod DB3). Rovněž koncentrace $\mathrm{Pb}$ a Co jsou na ploše odkaliště zvýšené oproti jeho okolí, pouze v jednom př́padě byl i na ploše odkaliště prokázán obsah obou prvků pod detekčním limitem (DB3). Medián naměřených hodnot koncentrací $\mathrm{Pb}$ činí 21,62 ppm, u Co pak 41,62 ppm. V okolí odkaliště bylo $\mathrm{Pb}$ a Co zjištěno pouze u odběrového bodu PH1. Analyticky zjištěné koncentrace Ni se pohybují v rozmezí od 24,48 (DB3) do 120,20 ppm (DB7). V okolí odkaliště dosahují, stejně jako $\mathrm{v}$ prrípadě všech předchozích prvků, svého maxima ve vzorku u odběrového bodu PH1, kde jeho hodnota činí 52,10 ppm. Koncentrace kadmia se ve všech vzorcích nacházejí pod detekčním limitem použitého přístroje. Mezi nejvýznamnější detekované kontaminanty patří arsen, jehož analyticky zjištěné maximum dosahuje hodnoty 593,35 ppm a medián koncentrací z plochy odkaliště činí 380,61 ppm. V případě všech vzorků odebraných v prostoru hráze a pod touto hrází ležela koncentrace arsenu vždy pod detekčním limitem přístroje. Obsahy všech analyzovaných polutantů na zájmové ploše jsou, s výjimkou kadmia, zvýšené oproti jejich průměrným koncentracím ve svrchní zemské kůře (AVG: $\mathrm{As}=4,8 ; \mathrm{Cd}=0,1 ; \mathrm{Co}$ $=17,3 ; \mathrm{Cu}=28,0 ; \mathrm{Ni}=47,0 ; \mathrm{Pb}=17,0 ; \mathrm{Zn}$ =67,0 ppm) (Rudnick 2014). Ze srovnání získaných dat s limitními hodnotami těžkých kovů publikovanými v Metodickém pokynu MŽP (MŽP 2013) vyplývá, že k mírnému překročení mezních hodnot $(\mathrm{As}=0,61 ; \mathrm{Cd}=70 ; \mathrm{Co}=23 ; \mathrm{Cu}=3100$; trace pod detekčním limitem.
$\mathrm{Ni}=1$ 500; $\mathrm{Pb}=400 ; \mathrm{Zn}=23$ 000, vše $\mathrm{v}$ ppm) došlo na odkališti pouze u kobaltu, mnohonásobně však u arsenu (v průměru víc než 500×). Přestože jsou pro tento prvek běžné mírně nadlimitní koncentrace na celém území České republiky, koncentrace nalezené na odkališti jsou alarmující. Obecně platí, že samotné překročení limitních hodnot ještě nemusí znamenat potenciální ohrožení ekosystému, proto se $\mathrm{v}$ př́ípadě zvýšeného překročení vytvářejí expoziční modely pro danou lokalitu a záměr. Pro studovanou lokalitu již byly v minulosti navrženy expoziční modely pro koncentrace As, a to jak pro vlastní rekreační využití, tak i pro stavební práce, spojené s jejím vybudováním (Ondráček 2009). Analýzy byly provedeny podobnou metodikou, jako v této práci: vzorky byly odebrány z hloubky prvních metrů pod povrchem a koncentrace těžkých kovů v nich byla stanovena atomovou emisní spektrometrií. Tyto modely vycházely $z$ tehdy naměřené průměrné (179 ppm) a maximální (385 ppm) koncentrace arsenu. Ondráček (2009) zmiňuje na studovaném úložišti možnost potenciálního zdravotního ohrožení organismu pouze $\mathrm{v}$ místech s maximální koncentrací arsenu, u nichž byla $\mathrm{v}$ př́padě karcinogenního rizika ELCR (Excess Lifetime Cancer Risk) vypočtena hodnota $3,30 \cdot 10^{-6}$. Vypočtená hodnota převyšuje limit $1 \cdot 10^{-6}$, jehož překročení signalizuje zvýšenou pravděpodobnost vzniku karcinogenního onemocnění. Prezentovaná práce však ukazuje, že i tato maxima (385 ppm) jsou v některých místech úložiště (DB4, DB6, DB8) překročena, což je v souladu i s pozdějšími výzkumy provedenými na lokalitě (např. Doleželová 2013 stanovila $\mathrm{As}_{(\mathrm{AVG})}=286$ ppm $\left.\mathrm{a} \mathrm{As}_{(\mathrm{MAX})}=638 \mathrm{ppm}\right)$.

Obsah rtuti se ve studovaných vzorcích pohybuje na hranici detekčního limitu (ND) použitého přístroje. Spektrální čára $L \alpha$ je v př́padě Hg v zákrytu s píkem $K \alpha$ Ge, jejíž intenzity ve vzorcích jsou vyšší, rtut tak lze předpokládat pouze u vzorků DB2, DB3, DB4, DB8 (tab. 2).

Tab. 2: Koncentrace rtuti a germania [ppm] na ploše odkaliště; < DL - Koncen-

Tab. 2: Concentration of mercury and germanium in the area of the waste dump [ppm]; $<\mathrm{DL}-\mathrm{A}$ concentration below the limit of detection.

\begin{tabular}{|c|c|c|c|c|c|c|c|c|}
\hline & \multicolumn{4}{|c|}{$\mathrm{Hg}$} & \multicolumn{4}{|c|}{$\mathrm{Ge}$} \\
\hline & 璃 & 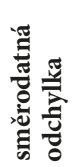 & 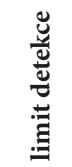 & 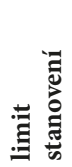 & 莺 & 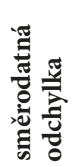 & 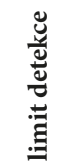 & 泀芯 \\
\hline DB1 & $<\mathrm{DL}$ & 7,41 & 22,20 & 66,70 & 131,00 & 4,75 & 5,08 & 15,20 \\
\hline DB2 & 17,60 & 3,73 & 9,74 & 29,20 & 46,50 & 2,30 & 2,93 & 8,80 \\
\hline DB3 & 17,30 & 4,47 & 11,70 & 35,00 & 13,10 & 2,53 & 6,42 & 19,30 \\
\hline DB4 & 32,50 & 6,90 & 18,70 & 56,10 & 106,00 & 4,41 & 7,11 & 21,30 \\
\hline DB5 & $<\mathrm{DL}$ & 7,29 & 21,20 & 63,70 & 179,00 & 5,50 & 6,19 & 18,60 \\
\hline DB6 & $<\mathrm{DL}$ & 10,70 & 32,00 & 95,90 & 235,00 & 7,79 & 14,80 & 44,40 \\
\hline DB7 & $<\mathrm{DL}$ & 7,72 & 22,00 & 66,00 & 96,40 & 4,79 & 7,23 & 21,70 \\
\hline DB8 & 27,00 & 7,53 & 21,10 & 63,60 & 153,00 & 7,73 & 5,00 & 15,00 \\
\hline
\end{tabular}


Tab. 3: Koncentrace $\mathrm{K}$, eU, eTh a vypočtené hodnoty hmotnostní aktivity ${ }^{226} \mathrm{Ra}\left(\mathrm{a}_{\mathrm{m}}\right)$

Tab. 3: Concentration of $\mathrm{K}, \mathrm{eU}$, eTh and calculated values of specific activity ${ }^{226} \mathrm{Ra}\left(\mathrm{a}_{\mathrm{m}}\right)$

\begin{tabular}{|l|c|c|c|c|c|c|c|}
\hline & $\begin{array}{c}\text { K } \\
{[\%]}\end{array}$ & STDEV & $\begin{array}{c}\text { eU } \\
{[\mathrm{ppm}]}\end{array}$ & STDEV & $\begin{array}{c}\text { eTh } \\
{[\mathrm{ppm}]}\end{array}$ & STDEV & $\begin{array}{c}\mathbf{a}_{\mathbf{m}} \\
{\left[\mathrm{Bq}_{\mathrm{kg}} \mathbf{- 1}\right]}\end{array}$ \\
\hline DB1 & 1,90 & 0,10 & 1,60 & 0,30 & 10,50 & 0,70 & 126,50 \\
\hline DB2 & 1,70 & 0,20 & 3,50 & 0,40 & 11,90 & 1,20 & 153,30 \\
\hline DB3 & 1,80 & 0,30 & 7,30 & 0,60 & 16,10 & 1,50 & 227,00 \\
\hline DB4 & 1,80 & 0,30 & 6,30 & 0,70 & 17,40 & 1,70 & 222,20 \\
\hline DB5 & 1,20 & 0,30 & 6,70 & 0,70 & 13,90 & 1,80 & 192,40 \\
\hline DB6 & 1,90 & 0,30 & 7,60 & 0,60 & 19,50 & 1,60 & 252,90 \\
\hline DB7 & 1,50 & 0,20 & 5,20 & 0,50 & 17,60 & 1,40 & 202,60 \\
\hline DB8 & 1,50 & 0,30 & 8,10 & 0,80 & 17,70 & 1,90 & 238,90 \\
\hline PH1 & 1,70 & 0,20 & 3,20 & 0,50 & 14,30 & 1,20 & 163,50 \\
\hline PH2 & 1,90 & 0,20 & 2,80 & 0,30 & 12,30 & 0,80 & 151,80 \\
\hline H1 & 2,20 & 0,20 & 1,80 & 0,30 & 11,30 & 0,80 & 140,90 \\
\hline H2 & 2,20 & 0,20 & 2,10 & 0,40 & 12,70 & 1,00 & 152,70 \\
\hline
\end{tabular}

U zbývajících vzorků není sice možné přítomnost rtuti vyloučit, její potenciální množství se však vždy nachází pod detekčním limitem přístroje. Prostřednictvím ED-XRF byly rovněž změřeny koncentrace výše uvedených těžkých kovů. Takto zjištěné koncentrace korelují s přesněji naměřenými koncentracemi vybraných polutantů metodou AAS a potvrzují tak rozptyl jejich zjištěných hodnot.

Laboratorní gamaspektrometrií byly v analyzovaném materiálu př́mo stanoveny koncentrace draslíku a nepřímo také koncentrace uranu (eU) a thoria (eTh). Výsledky doplněné o vypočtenou hmotnostní aktivitu ekvivalentu ${ }^{226} \mathrm{Ra}$ (Beretka a Matthew 1985), $\mathrm{a}_{\mathrm{m}}$, jsou uvedeny v tabulce 3. Limitní hodnota $\mathrm{a}_{\mathrm{m}}$, stanovená Beretkou a Matthewem (1985) na $370 \mathrm{~Bq} \mathrm{~kg}^{-1}$, nebyla ani u jednoho vzorku na odkališti Brno-Hády překročena. Zhodnocení př́tomnosti prrirozených radionuklidů potvrdilo na zkoumané ploše lokálně jen jejich mírně zvýšené koncentrace, zjištěná množství však nepředstavují potenciální riziko ohrožení okolního ekosystému. S ohledem na nízké koncentrace přirozených radionuklidů by bylo naopak možné uvažovat o využití deponovaných popílků v rámci rekultivace lokality jako materiálu vhodného pro stavební účely, nebot' ani limitní hodnota hmotnostní aktivity platná aktuálně pro betonový materiál (300 $\left.\mathrm{Bq} \mathrm{kg}{ }^{-1}\right)$ nebyla jak v odebraných vzorcích, tak ani v publikovaných výzkumných zprávách z této lokality (Hela et al. 2013; Ondráček 2009) zaznamenána.

\section{Závěr}

Odkaliště Brno-Hády představuje jeden z př́ikladů antropogenního ovlivnění studovaného území v minulém století. Jeho rekultivace a následná udržitelnost patř́i z environmentálního pohledu k aktuálním otázkám dnešní doby. Výsledky práce upozorňují na případná zdravotní rizika spojená $s$ dalším možným využitím této lokality.

Studium popílků pomocí elektronového mikroskopu potvrdilo ve zkoumaném materiálu přítomnost mikrosfér jako typických produktů vysokoteplotního spalování uhlí. Z morfologického hlediska byly identifikovány částice nedopalu vyskytující se společně s cenosférami či plerosférami. Přítomné mikrosféry dosahují v průměru menší velikosti, než jsou rozměry běžně uváděné v literatuře, což může být $\mathrm{i}$ jednou z př́ícin zvýšené koncentrace polutantů.

Z výsledků atomové absorpční spektrometrie vyplývá, že zájmová lokalita byla v průběhu ukládání odpadu sekundárně obohacena o těžké kovy ( $\mathrm{Cu}, \mathrm{Zn}, \mathrm{Ni}, \mathrm{Co}, \mathrm{Pb})$, jejich koncentrace vyjma kobaltu však zůstala v podlimitních hodnotách. Dále lokalita vykazuje vysoké obohacení arsenem, jehož množství výrazně převyšuje doporučené limity. Analyticky identifikovatelné koncentrace $\mathrm{Hg}$ byly potvrzeny jen u poloviny odebraných vzorků a jejich množství se zpravidla pohybuje na hranici detekčního limitu ED-XRF použitého přístroje. Přítomnost kadmia nebyla prokázána. Většina kontaminantů potvrzených v deponovaných popílcích nepředstavuje potenciální zdravotní ohrožení obyvatelstva. Limitní hodnoty již dříve vypracovaných expozičních modelů naopak výrazně přesahují koncentrace arsenu.

Na základě hodnot získaných přepočtem naměřených obsahů přirozených radionuklidů na hmotnostní aktivitu ekvivalentního množství ${ }^{226} \mathrm{Ra}$ a porovnání koncentrací těchto prvků a těžkých kovů v prostoru odkaliště i v jeho bezprostředním okolí, lze v souladu s dřívějšími výsledky považovat lokalitu bývalého odkaliště popílků Brno-Hády z hlediska ohrožení okolního ekosystému za bezpečnou.

Za potenciálně rizikovou lze tudíž označit pouze přítomnost arsenu, jehož koncentrace v uložených odpadech by si za předpokladu využívání studovaného území jako volnočasového rekreačního areálu nutně vyžádaly další sanační zásahy.

\section{Poděkování}

Autoři děkují recenzentům doc. Ing. Jiřimu Faimonovi, Dr., Mgr. Daliborovi Všianskému, Ph.D., doc. Mgr. Radku Škodovi, Ph.D. a kolegovi Bc. Petru Štursovi za připomínky a rady, které vedly ke značnému zkvalitnění predloženého príspèvku. 


\section{Literatura}

Beretka, J., Matthew, P. J. (1985). Natural radioactivity of Australian building materials, industrial wastes and by-products. Health Phys. 48, 87-95.

Doleželová, S. (2013). Odkaliště sypkých průmyslových odpadů jako specifický druh ekologických zátěží. - MS, bakalářská práce. Katedra biologie, Pedagogická fakulta Masarykovy univerzity. Brno.

Fečko, P., Kušnierová, M., Lyčková, B., Čablík, V., Farkašová, A. (2003). Popílky - Vysoká škola báňská - Technická univerzita. Ostrava.

Gilíková, H., Hladil, J. (eds), Bubík, M., Černý, J., Hrdličková, K., Kunceová, E., Melichar, R., Otava, J., Tomanová Petrová, P., Vít, J. (2010). Základní geologická mapa České republiky 1 : 25 000, list 24-413 Mokrá-Horákov. - MS, Česká geologická služba. Praha.

Hanžl, P. (ed.), Baldík, V., Bubík, M., Buriánek, D., Dolníček, Z., Dvořák, I., Fürychová, P., Havlín, A., Hrdličková, K., Kociánová, L., Konečný, F., Krejčí, O., Krejčí, Z., Krumlová, H., Kryštofová, E., Müller, P., Paleček, M., Pecina, V., Pecka, T., Poul, I., Sedláčková, I., Skácelová, D., Skácelová, Z., Slobodník, M., Šrámek, J., Tomanová Petrová, P., Večeřa, J., Vít, J. (2020). Vysvětlivky k Základní geologické mapě České republiky 1 : 25 000, list 24-324 Brno-sever. 152 s. - Česká geologická služba. Praha

Hela, R., Sokol, P., Donát, P., Košařová, G., Orsáková, D. (2013). Popílek v betonu. - ČEZ Energetické produkty s.r.o. Brno.

Moric, P. (1997). Odkaliště Hády: doplňkový inženýrskogeologický a hydrogeochemický průzkum. - MS, doplňkový průzkum. Aquatis a. s. Brno.

Ondráček, P. (2009). Odkaliště Hády-analýza rizika. - MS, závěrečná práce. Envi Aqua, s.r.o. Brno.

MŽP (2013). Indikátory znečištění. - Metodický pokyn MŽP. Ministerstvo životního prostředí. Praha. Dostupné z: Microsoft Word - MP Indikátory znečištění_2013_v2.doc (mzp.cz)

Př́kazská, M. (2017). Je bývalé odkaliště Brno-Hády ekologickým rizikem? - MS, středoškolská odborná činnost. Gymnázium Brno, Vídeňská. Brno.

Rudnick, R. (2014). Treatise on Geochemistry, The Crust. - Composition of the Continental Crust, vol 4, 1-51.

Štelcl, J., Weiss, J. (eds) (1986). Brněnský masív. - Univerzita Jana Evangelisty Purkyně. Brno. 255 s. 